\title{
Effect of Bridge Grafting the M9 Self-rooted Rootstock in Trunk-wounded Apple Trees on Vegetative Growth, Yield, and Fruit Characteristics
}

\author{
Chenping Zhou, Ruiting Chen, Yaqiang Sun, He Wang, Yi Wang, \\ Ting Wu, Xinzhong Zhang, Xuefeng Xu, and Zhenhai Han \\ College of Horticulture, China Agricultural University, Beijing 100193, P.R. \\ China; Key Laboratory of Stress Physiology and Molecular Biology for Fruit \\ Trees in Beijing Municipality, China Agricultural University, Beijing \\ 100193, P.R. China; and Key Laboratory of Biology and Genetic \\ Improvement of Horticultural Crops (Nutrition and Physiology), Ministry \\ of Agriculture, China Agricultural University, Beijing 100193, P.R. China
}

Additional index words. apple tree, bridge grafting, trunk wounding, M9 self-rooted rootstock

Abstract. Bridge grafting is widely applied in trunk-wounded apple trees. In this study, we carried out semigirdling and ring girdling on the trunk of 'Nagafu 2'/Malus baccato (L.) Borkh apple trees to simulate trunk injury. We then bridge grafted a M9 self-rooted rootstock on the injured trunks to study the effects of bridge grafting on flowering, fruitset, tree vigor, and fruit characteristics in 'Nagafu 2' apple. The results showed that both semigirdling and ring girdling due to the large wounded area caused significant decrease in flowering, fruit-set, and tree vigor (estimated by measuring leaf area, leaf gas exchange, tree height, and shoot growth); in addition, ring girdling increased flesh and peel firmness. However, bridge grafting of M9 self-rooted rootstock on semigirdling and girdling apple trees resulted in partial recovery of tree vigor (leaf area and photosynthesis) and maintaining the reduction of vegetative growth, thereby increasing flowering, fruit-set, yield, fruit weight, and peel firmness.

In China, apple is an important economic fruit crop that is threatened by trunk wounding, which can seriously restrict the development of the apple fruit industry (Wang et al., 2014). In general, trunk injury caused by Valsa canker, mechanical wounding, and other factors, such as winter cold and animal biting, limits the growth and fruit yield of apple trees (Goren et al., 2004; Tan et al., 2017). Valsa canker is a major cause of severe injury to the trunks of apple trees in China, Japan, and Korea (Abe et al., 2007; Hu et al., 2014; Lee et al., 2006; Wang et al., 2005). In 2008, the incidence rate of Valsa canker was as high as $52.7 \%$ in the investigated orchard and the disease tended to spread in an unchecked manner (Cao et al., 2009). According to Ma et al. (2007), $\approx 65 \%$ of 13- to 17-year-old 'Nagafu 2' apple trees

Received for publication 11 Apr. 2018. Accepted for publication 11 May 2018.

This study was supported by the National Key Research and Development Program of China (2016YFD0201100), the earmarked fund for China Agriculture Research System (CARS-27), and grants from the Beijing Municipal Education Commission (CEFF-PXM2017_014207_000043).

We thank Fengwang Ma (College of Horticulture, Northwest A\&F University) who provided the field of apple trees for this study at the Apple Experimental Station, Luochuan, Shaanxi, China.

${ }^{1}$ Corresponding author. E-mail: rschan@cau.edu.cn. were infected by Valsa canker disease in Shaanxi Province, China.

Severe injury to the trunk of apple trees might affect water, nutrient, and photoassimilate flow from the source to sink organs. This damage can retard growth, reduce photosynthesis, cause leaf chlorosis and abscission, and affect fruit characteristics. It might even cause the death of trees (Fanwoua et al., 2014; Poirier-Pocovi and Buck-Sorlin, 2016; Singh et al., 2015).

Injury to the trunk of fruit trees causes the accumulation of insoluble carbohydrates, such as starch, above the trunk wounds, whereas soluble carbohydrate content decreases, thereby activating glycolysis to match the increased energy requirement (Beruter et al., 1997; Jordan and Habib, 1996; Rivas et al., 2006). In addition, trunk wounding reduces the concentration of cytokinins (CTK), auxin, and abscisic acid (ABA), while significantly increasing the gibberellin acid (GA) content in the shoots (Dann et al., 1985; Skogerbo, 1992). This hormone imbalance caused by trunk girdling might be associated with the altered carbohydrate metabolism, root growth, and vegetative growth (An et al., 2017).

Bridge grafting has been widely used to treat trunk wounds in apple trees. The application of bridge-grafting technology has been shown to alleviate low apple yield and improve fruit characteristics in trunk-wounded apple trees. However, very little is known about the effect of bridge grafting on vegetative growth, yield, and fruit characteristics in Valsa cankerinduced trunk-wounded 'Nagafu 2' (Red Fuji) apple trees, with regard to the severity of Valsa canker in the region of Chinese apple cultivation, especially in the western part of China. In the present study, to simulate apple tree trunk injury, which is caused by scraping of the infected trunk bark that is commonly used to prevent the spread of Valsa canker disease in apple orchards, we used the method of artificial debarking of trunk in 5-year-old 'Nagafu 2' $/ M$. baccata (L.) Borkh apple trees. Next, we planted a M9-T337 (M9) self-rooted rootstock adjacent to every tree to bridge graft the wounded trunks. Subsequently, we investigated flowering, fruit-set, plant vigor, fruit characteristics, leaf photosynthesis, shoot hormone, and carbohydrate content in the bridge-grafted, girdled apple trees to better understand the effect of M9 bridge grafting on trunkwounded apple trees and to provide empirical guidance for addressing the problem of severe Valsa canker disease requiring the digging of apple trees.

\section{Materials and Methods}

Plant materials. This experiment was performed at the Apple Experimental Station, Luochuan, Shaanxi, China (lat. $35^{\circ} 47^{\prime} \mathrm{N}$, long. $109^{\circ} 22^{\prime} \mathrm{E}$ ), from Apr. 2016 to Oct. 2017. We used 5-year-old 'Nagafu 2' (Red Fuji) on apple rootstocks $M$. baccata (L.) Borkh, planted at a spacing of $5.0 \times 3.0 \mathrm{~m}$ in loess soil. The trees were maintained according to local commercial standards throughout the study.

Experimental design. The experiment was performed as described by Samad et al. (1999b) and Tang et al. (2015), with some modifications. The experiment was a two by two factorial design with no girdling and girdling (semigirdling and ring girdling) by two bridge grafting of M9 treatments (treated and untreated). Forty trees were used in a completely randomized design. Experiments were performed using 3-30 replications. The following five treatments were used in this study: 1) no girdling or bridge grafting (control), 2) semicircle girdling of the trunk bark $(1 / 2 \mathrm{G}), 3)$ bridge grafting of 1-year-old M9 self-rooted rootstock on $1 / 2 \mathrm{G}(1 / 2 \mathrm{G}+\mathrm{M} 9)$, 4) full-circle girdling of the trunk bark (G), and 5) bridge grafting an M9 on $\mathrm{G}(\mathrm{G}+\mathrm{M} 9)$ (Fig. 1).

On 5 Apr. 2016, an $\approx 2.0$-cm width bark strip was removed from the trunk, $30 \mathrm{~cm}$ above the ground, for the $1 / 2 \mathrm{G}$ and $\mathrm{G}$ apple trees treatments. In addition, an M9 rootstock was planted adjacent to each experimental apple tree for bridge grafting after survival (1 week). A 1.0-cm-wide split M9 was inserted, with cambial matching at $\approx 10 \mathrm{~cm}$ intervals up to the wound on the $1 / 2 \mathrm{G}$ and $\mathrm{G}$ apple trees, which were labeled as $1 / 2 \mathrm{G}+\mathrm{M} 9$ and $\mathrm{G}+\mathrm{M} 9$, respectively. Subsequently, the graft was tightly wrapped with plastic and rope to prevent the entry of moisture and insect pests. Untreated trees were used as controls. Three replications were used per treatment, and one tree per replication.

Data collection and leaf photosynthesis measurements. The leaf area was determined 
A

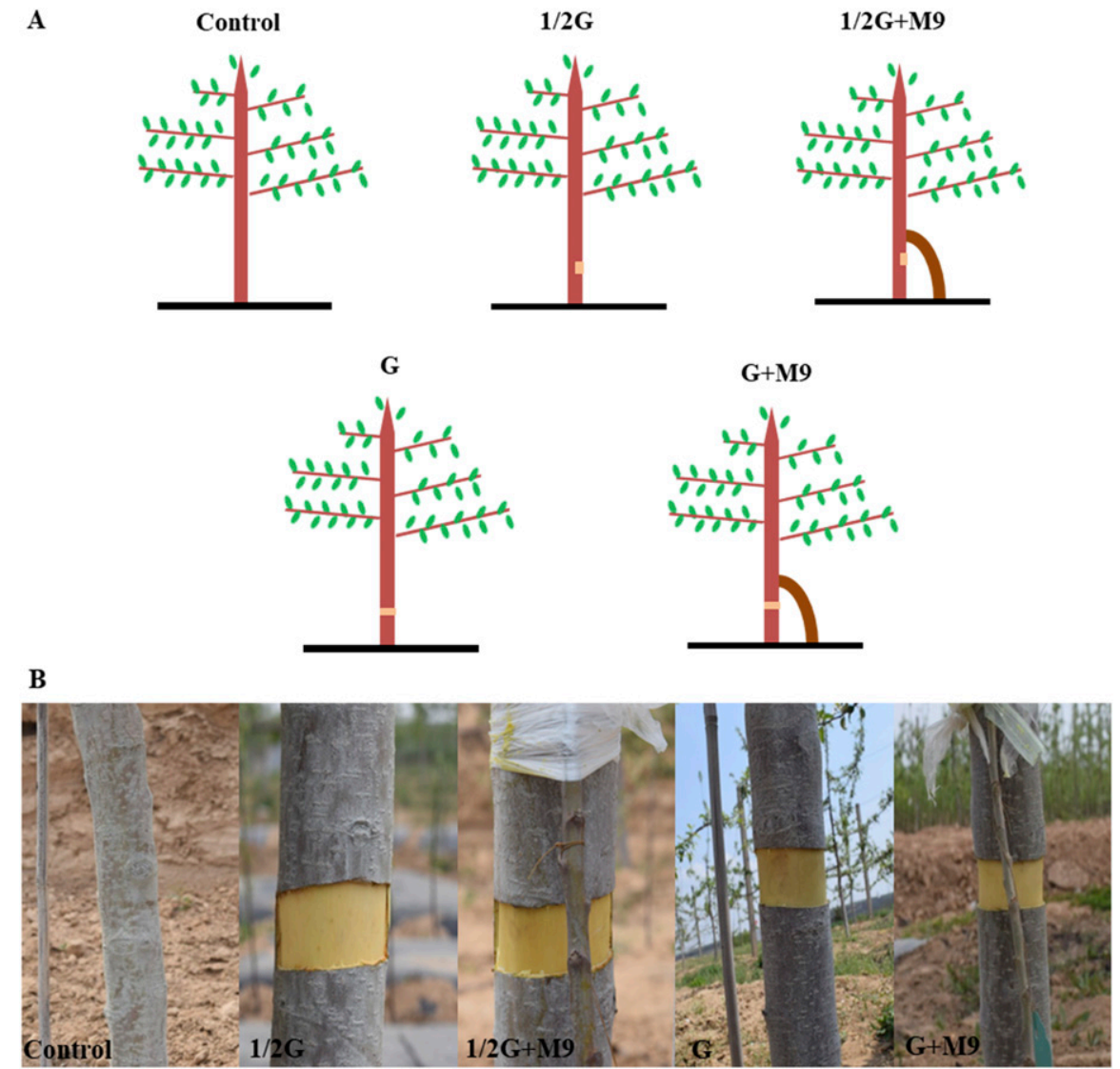

$1 / 2 \mathrm{G}$

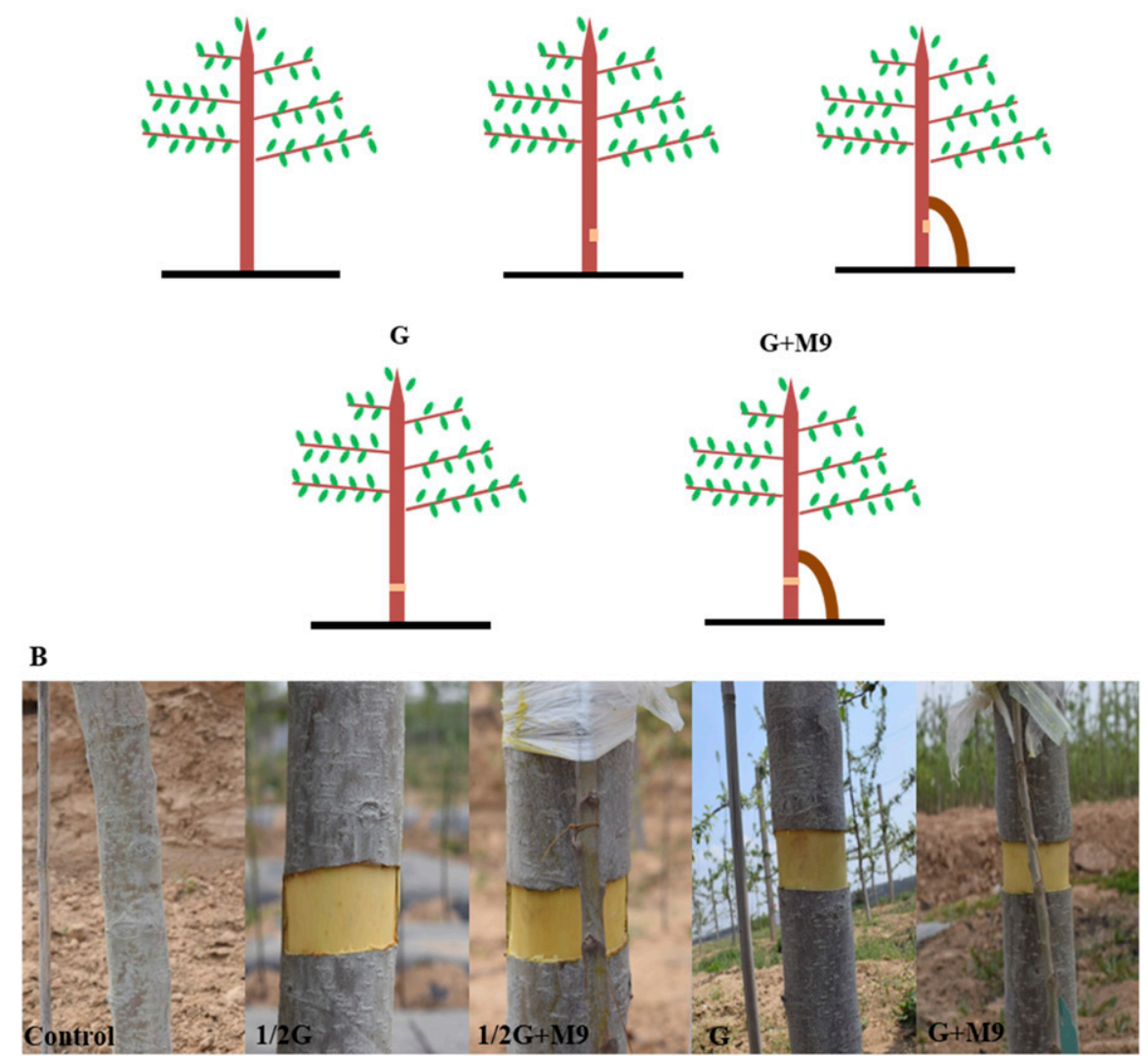

Fig. 1. Sketch of different treatments for girdling and bridge grafting of M9 rootstocks on the girdled trunk of 'Nagafu 2' trees (A) and photographs of different treatments in 2016 (B). Control = no girdling or no bridge grafting apple trees; $1 / 2 \mathrm{G}=$ semigirdling apple trees; $1 / 2 \mathrm{G}+\mathrm{M} 9=$ bridge-grafted $\mathrm{M} 9$ on semigirdling apple trees; $\mathrm{G}=$ ring girdling apple trees; $\mathrm{G}+\mathrm{M} 9$ = bridge-grafted $\mathrm{M} 9$ on ring girdling apple trees. on 20 Aug. 2017, by using 10 leaves from each tree. On 20 Dec. 2016, selected 10 annual shoot length per tree crown, tree height, total floral bud number, number of spurs, and medium-long shoots from six main branch per tree were investigated. The number of flowers at full blossom (18 Apr. 2017) and the number of fruit at $30 \mathrm{~d}$ after full blossom per tree were recorded. The number of spring shoots was measured when spring shoots stopped growing, on 10 July 2017. Every month, from 10 June to 10 Sept. in 2016, shoot terminals with 7-10 leaves were collected and 1-cm long shoot tips from each shoot terminal were cut, lyophilized, frozen in liquid nitrogen, and stored at $-80{ }^{\circ} \mathrm{C}$ until extraction for the determination of hormones, carbohydrates, and soluble protein. Nine replications were used per treatment (one shoot per replication and three shoots per tree).

On 20 July 2017, the leaf net photosynthetic rate $(P \mathrm{n})$, stomatal conductance $\left(g_{\mathrm{s}}\right)$, and transpiration rate $(\mathrm{Tr})$ of the leaves were measured using a LI-6400XT portable photosynthesis system (LI-COR, Inc., Lincoln, $\mathrm{NE}$ ), between 8:30 AM and 10:30 AM on a clear day, at ambient $\mathrm{CO}_{2}$ concentration and under a controlled light intensity of $1000 \mu \mathrm{mol} \cdot \mathrm{m}^{-2} \cdot \mathrm{s}^{-1}$. During measurements, leaf temperature and vapor pressure deficit were $26.9 \pm 1.1^{\circ} \mathrm{C}$ and $2.0 \pm 0.1 \mathrm{kPa}$, respectively. A portable soil and plant analyzer development meter (SPAD-502; Yikangnong, Shanghai, China) was used to measure the leaf chlorophyll content. Nine replications were used per treatment, one leaf per replication and three leaves per plant.

Determination of content of endogenous hormones, carbohydrates, and soluble protein. Endogenous hormones content in shoot tips was determined using an HPLC system (Waters, Milford, MA) according to Zhang et al. (2015). Standard protocols were used for hormone identification and quantification: ABA, GA, indole acetic acid (IAA), and zeatin riboside $(\mathrm{ZR})$ were separated and quantified using an Intertsil C18 ODS-3 chromatographic column $(150 \mathrm{~mm} \times 4.6 \mathrm{~mm}$, $5 \mu \mathrm{m}$; Sigma Aldrich, St. Louis, MO) and a Waters 2487 detector ( $k=280 \mathrm{~nm}$; Waters). The mobile phase consisted of methanol and $0.5 \%$ acetic acid $(60: 40, \mathrm{v} / \mathrm{v})$, the flow rate was $1 \mathrm{~mL} \cdot \mathrm{min}^{-1}$, and the column temperature was $30^{\circ} \mathrm{C}$. Solutions of $0.1 \mathrm{~g} \cdot \mathrm{L}^{-1} \mathrm{ZR}, 20.0 \mathrm{~g} \cdot \mathrm{L}^{-1} \mathrm{GA}$, $1.0 \mathrm{~g} \cdot \mathrm{L}^{-1} \mathrm{IAA}$, and $0.1 \mathrm{~g} \cdot \mathrm{L}^{-1} \mathrm{ABA}$ were used as standard samples.

Soluble sugar and starch concentrations were measured following the method of Rose et al. (1991) and Yemm and Willis (1954), respectively. Shoot tips soluble protein was extracted and determined as described by Zhou et al. (2013).

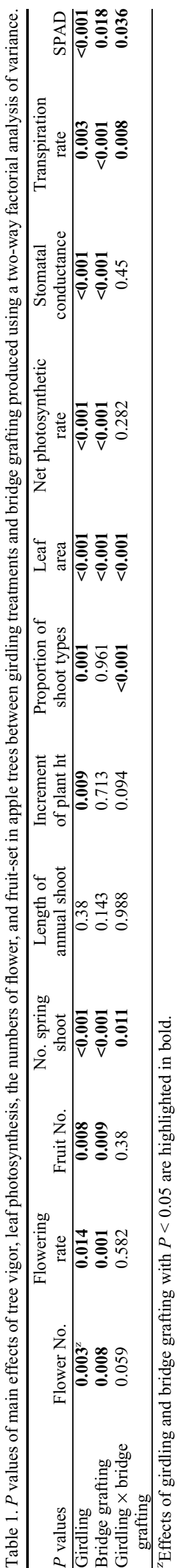


Determination of fruit characteristics. Fruit production per apple tree and single fruit weight were measured on 19 Oct. 2017, by using an electronic scale. Ten fruits from every tree were sampled for the determination of fruit characteristics (one apple fruit per replication and 10 fruits per tree). Fruit length and fruit diameter of the apples were measured using a vernier caliper; chromaticity of the fruit peel was determined using a Reflectance Tintometer (Lovibond RT Series, Dortmund, Germany). Soluble-solid content in the fruit flesh was measured using a pocket refractometer (Atago, Tokyo, Japan); the fruit maturity index was calculated as described by Blanpied and Silsby (2010). Fruit firmness was estimated by the force required for puncturing the fruit in the middle using a TA. XT Express Texture Analyzer (Stable Micro Systems, Hamilton, South Lanarkshire, UK) and the data were analyzed using the exponent system (Stable Micro Systems).

Statistical analysis. Correlation coefficients were calculated using the Pearson correlation analysis procedure and means were separated using the least significant difference test at $P<0.05$. Flowering, fruitset, plant height, shoot number, photosynthesis data, yield, and fruit characteristics were tested using two-way analysis of variance (ANOVA). Hormones, carbohydrates, and soluble protein were tested using three-way ANOVA. All data were analyzed using IBM SPSS software (IBM Corporation, New York).

\section{Results}

Effect of bridge grafting on flowering and fruiting. In 2016 and 2017, the results of bridge-grafted M9 rootstocks on trunk-wounded 'Nagafu 2' trees were successful, but the trunk wounds were healing faultily (Fig. 1; Supplemental Fig. 1). Bridge-grafted M9 significantly affected flowering in both semigirdled and girdled 'Nagafu 2' trees. We counted the number of flowers in the apple trees during bloom and found that the flower number of $1 / 2 \mathrm{G}$ and $\mathrm{G}$ apple trees was lower than that in the controls $(P=0.003)$. Furthermore, the number of flowers in $1 / 2 \mathrm{G}+\mathrm{M} 9$ and $\mathrm{G}+\mathrm{M} 9$ apple trees was $40.5 \%$ and $85 \%$ greater $(P=0.008)$ than that in $1 / 2 \mathrm{G}$ and $\mathrm{G}$ apple trees, respectively. Finally, neither of the two treatments was significantly different from the control trees (Fig. 2A; Table 1). In the treatments, $\approx 30 \%$ floral buds blossomed into flowers $(P=0.014)$; however, in the control and bridge-grafted 'Nagafu 2' trees, $60 \%$ floral buds blossomed $(P=0.001$; Supplemental Fig. 2).

Fruit-set was increased by bridge grafting in $1 / 2 G$ and $G$ treatment apple trees. The $G$ apple trees showed the lowest number of fruits among all treatments, whereas the fruit number of $1 / 2 \mathrm{G}$ trees was not significantly different from that of the other four treatments $(P=0.008$; Fig. 2B; Table 1). Bridgegrafted M9 led to an increase of $21.5(33.3 \%)$ and $39.7(55.4 \%)$ fruits/tree in $1 / 2 \mathrm{G}$ and $\mathrm{G}$ apple trees, respectively $(P=0.009)$.

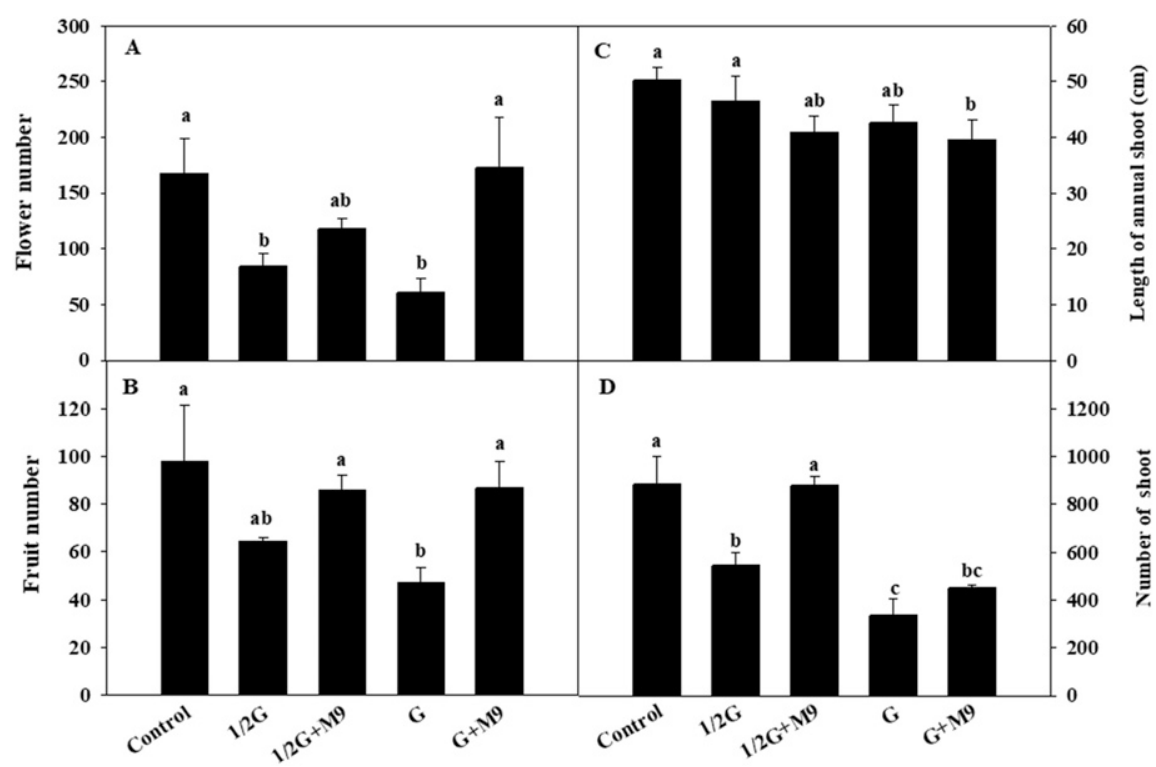

Fig. 2. Effects of semigirdling, ring girdling, and bridge grafting of M9 on flower number in full-bloom stage (A), fruit-setting number at $30 \mathrm{~d}$ after flowering (B), annual shoot length (C), and number of spring shoot in 2017 (D) in 'Nagafu 2' trees. Control = no girdling or no bridge grafting apple trees; $1 / 2 \mathrm{G}=$ semigirdling apple trees; $1 / 2 \mathrm{G}+\mathrm{M} 9$ = bridge-grafted $\mathrm{M} 9$ on semigirdling apple trees; $\mathrm{G}=$ ring girdling apple trees; $\mathrm{G}+\mathrm{M} 9=$ bridge-grafted $\mathrm{M} 9$ on ring girdling apple trees. Bars represent mean $\pm \mathrm{SE}$, $n=3$. Different letters above the bars indicate a significant difference at $P<0.05$.

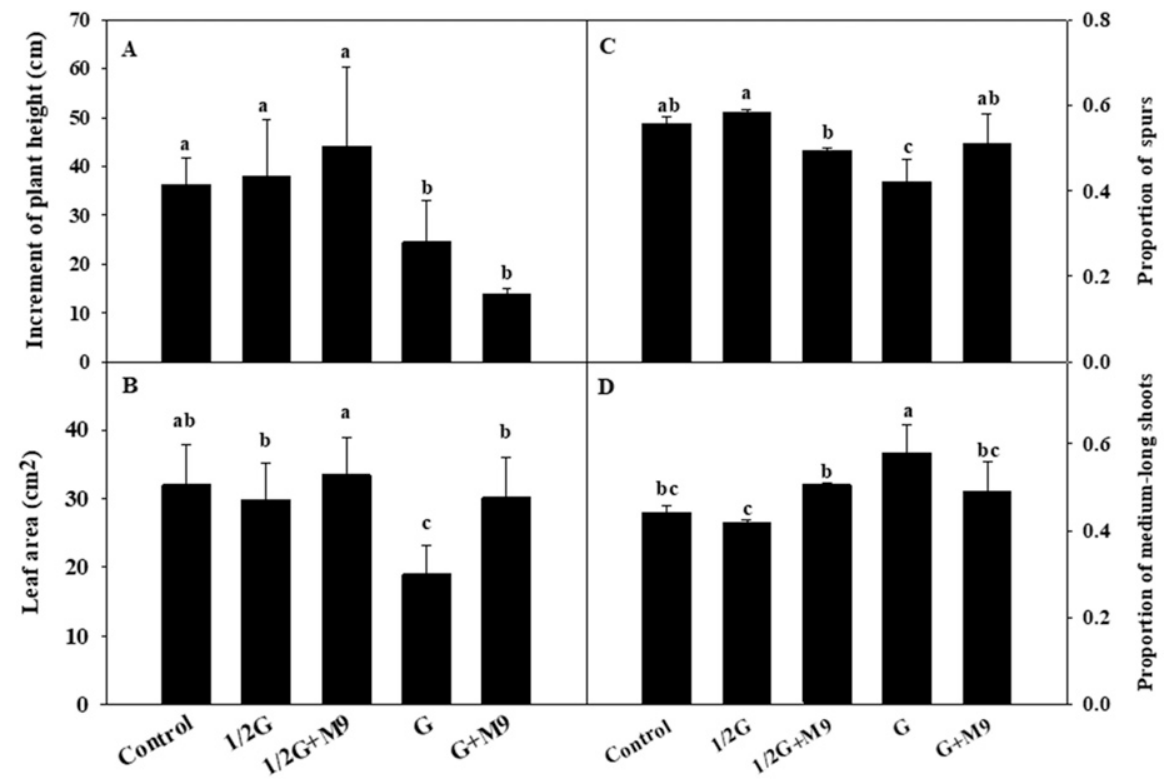

Fig. 3. Effects of semigirdling, ring girdling, and bridge grafting of M9 on increment of plant height (A), leaf area (B), proportion of spurs (C), and proportion of medium-long shoots (D) in 'Nagafu 2' trees. Control $=$ no girdling or no bridge grafting apple trees; $1 / 2 \mathrm{G}=$ semigirdling apple trees; $1 / 2 \mathrm{G}+\mathrm{M} 9=$ bridge-grafted M9 on semigirdling apple trees; $\mathrm{G}=$ ring girdling apple trees; $\mathrm{G}+\mathrm{M} 9$ = bridge-grafted M9 on ring girdling apple trees. Bars represent mean $\pm \mathrm{SE}, n=3-30$. Different letters above the bars indicate a significant difference at $P<0.05$.

Table 2. Correlation coefficients between tree vigor and the number of flower and fruit-set.

\begin{tabular}{lcccc}
\hline Correlation coefficients & Fruit-set & Shoot No. & Increment of plant ht & Ratio of spurs \\
\hline Flower number & $0.685^{* *}$ & 0.396 & -0.198 & 0.225 \\
Fruit-set & & $0.674^{* *}$ & 0.045 & $0.538^{*}$ \\
Shoot number & & $0.516^{*}$ & 0.304 \\
Increment of plant height & & & 0.043 \\
\hline
\end{tabular}


Effects on development of tree height, shoot, and leaf. The shoot length in G+M9 apple trees was significantly shorter than that in the control $(21.14 \%)$ and $1 / 2 \mathrm{G}(17.69 \%)$ apple trees, whereas it was not significantly different from that of $1 / 2 \mathrm{G}+\mathrm{M} 9$ or $\mathrm{G}$ apple trees (Table 1). Moreover, the shoot length in the control, $1 / 2 \mathrm{G}, 1 / 2 \mathrm{G}+\mathrm{M} 9$, and $\mathrm{G}$ apple trees decreased gradually, and no significant difference was noted between them $(P>$ 0.05 ; Fig. 2C; Table 1). The removed bark area of the trunk was closely related to the number of spring shoots. The spring shoot number in $G$ apple trees was the lowest, whereas the shoot number of G+M9 apple trees was $25.78 \%$ higher than that of the former $(P<0.001$; Fig. 2D). The shoot number in $1 / 2 \mathrm{G}+\mathrm{M} 9$ apple trees was significantly higher than that in $1 / 2 \mathrm{G}$ apple trees, which was similar to the shoot number in the control trees.

Removal of a ring of a bark around the trunk slowed the growth of apple trees, regardless of bridge grafting of the M9 self- rooted rootstocks onto the tree trunk (Fig. 3A; Table 1). In addition, the removal of the bark around the trunk seriously affected the leaf growth. The leaf area of $\mathrm{G}$ apple trees was $68.51 \%$ and $62.8 \%$ smaller than that of the control and $\mathrm{G}+\mathrm{M} 9$ apple trees, respectively $(P=0.009)$. In addition, bridge grafting of M9 on $1 / 2 \mathrm{G}$ apple trees increased the leaf area compared with that of $1 / 2 \mathrm{G}$ apple trees $(P<0.001)$. The size of the bark ring removed was a crucial factor affecting the leaf growth in apple trees. The leaf area in $1 / 2 \mathrm{G}$ apple trees was significantly larger than that in $\mathrm{G}$ apple trees $(P<0.001$; Fig. 3B; Table 1$)$. The proportion of spurs in $\mathrm{G}$ apple trees was lower, and the ratio of medium-long shoots was higher than those in the other four treatments $(P=0.001$; Fig. $3 \mathrm{C}$ and $\mathrm{D})$.

Apple yield was closely related to the growth status of the trees. Flower number and tree vigor determined fruit-set and the increase in the ratio of spurs, which were the main fruit-bearing shoots, thereby contributing the most to fruit yield $(P<0.01$; Table 2$)$.

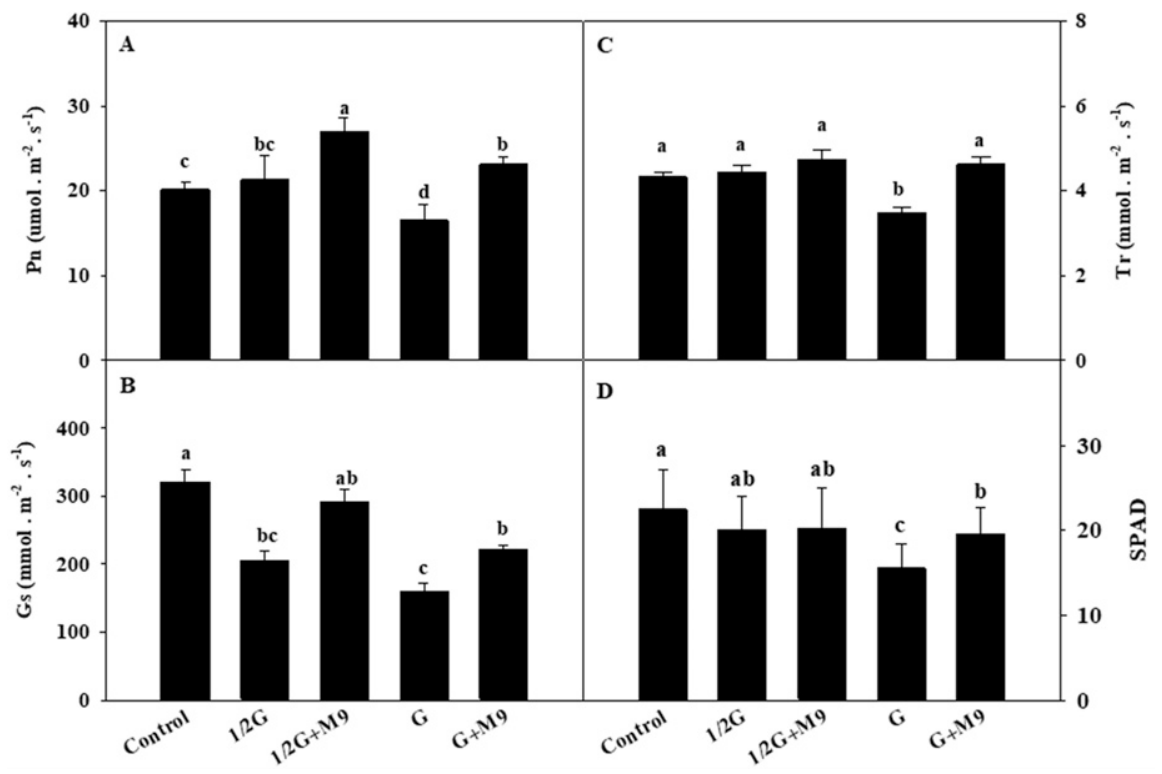

Fig. 4. Effects of semigirdling, ring girdling, and bridge grafting of $\mathrm{M} 9$ on leaf net photosynthetic rate $(P \mathrm{n})$ (A), stomatal conductance $\left(g_{\mathrm{s}}\right)(\mathbf{B})$, transpiration rate $(\mathrm{Tr})(\mathbf{C})$, and SPAD values in 'Nagafu 2' trees. Control $=$ no girdling or no bridge grafting apple trees; $1 / 2 \mathrm{G}=$ semigirdling apple trees; $1 / 2 \mathrm{G}+\mathrm{M} 9=$ bridge-grafted $\mathrm{M} 9$ on semigirdling apple trees; $\mathrm{G}=$ ring girdling apple trees; $\mathrm{G}+\mathrm{M} 9=$ bridge-grafted M9 on ring girdling apple trees. Bars represent mean $\pm \mathrm{SE}, n=9$. Different letters above the bars indicate a significant difference at $P<0.05$.

Effects on photosynthetic parameters. Bridge grafting of M9 self-rooted rootstocks onto $1 / 2 \mathrm{G}$ and $\mathrm{G}$ apple trees increased the $P \mathrm{n}$, $g_{\mathrm{s}}$, and $\mathrm{Tr}$ in leaves $(P<0.001$; Fig. $4 \mathrm{~A}-\mathrm{C}$; Table 1$)$. Leaf $P$ n was significantly higher in $1 / 2 \mathrm{G}+\mathrm{M} 9$ and $\mathrm{G}+\mathrm{M} 9$ apple trees than in the control trees. Conversely, $P \mathrm{n}$ in $1 / 2 \mathrm{G}+\mathrm{M} 9$ and $\mathrm{G}+\mathrm{M} 9$ was higher than that in control, and a significant difference was noted between $\mathrm{G}$ and control (Fig. 4A). Bridge grafting of M9 self-rooted rootstocks increased the leaf $g_{\mathrm{s}}$ of $\mathrm{G}$ apple trees, which was lower than that in controls. Phloem girdling of apple tree trunk significantly affected the leaf Tr; however, bridge grafting of M9 recovered the Tr.

Similarly, girdling obviously declined leaf SPAD, which was significantly lower than that in $\mathrm{G}+\mathrm{M} 9$ trees $(P=0.018)$. No significant difference in SPAD values was noted between $1 / 2 \mathrm{G}$ and $1 / 2 \mathrm{G}+\mathrm{M} 9$ trees (Fig. 4D).

Effects on fruit characteristics. The fruit numbers in the mature stage of control, $1 / 2 \mathrm{G}$, $1 / 2 \mathrm{G}+\mathrm{M} 9, \mathrm{G}$, and $\mathrm{G}+\mathrm{M} 9$ trees were lower by $9.2 \%, 35.9 \%, 16.3 \%, 46.8 \%$, and $18.4 \%$ than those in full blossom, respectively. Fruit yield, weight, diameter, and length in the $1 / 2 G$ and $G$ apple trees were significantly lower than those in the $1 / 2 \mathrm{G}+\mathrm{M} 9$ and $\mathrm{G}+\mathrm{M} 9$ treatments $(P<0.001)$. The color of the fruit peel in $\mathrm{G}$ apple trees was inferior to that observed in the other treatments $(P<0.001)$, but the fruit soluble-solid content in $\mathrm{G}$ apple trees was higher than that in the other treatments. Fruit shape index and maturity index were not significantly different among the treatments (Table 6).

The peel firmness $(P<0.001)$ and peel toughness $(P<0.001)$ were increased under $1 / 2 \mathrm{G}$ and $\mathrm{G}$ treatments and were higher in $\mathrm{G}$ than in $1 / 2 \mathrm{G}$ trees (Table 3 ). Nevertheless, bridge grafting of M9 decreased the flesh firmness in girdled apple trees $(P=0.023)$. The flesh firmness was significantly and negatively correlated with fruit yield and fruit length $(P<0.05)$, whereas the fruit soluble-solid content was significantly and negatively correlated with fruit diameter $(P<$ 0.05; Table 4).

Content of endogenous hormones, carbohydrates, and soluble protein. The ZR concentration in shoot tips of apple trees decreased gradually from June to September

Table 3. Texture of apple flesh and peel at different treatments.

\begin{tabular}{lcccc}
\hline Treatments & Peel firmness $\left(\mathrm{kg} \cdot \mathrm{cm}^{-2}\right)$ & Peel toughness $\left(\mathrm{kg} \cdot \mathrm{cm}^{-2}\right)$ & Flesh firmness $\left(\mathrm{kg} \cdot \mathrm{cm}^{-2}\right)$ & Flesh crispness $\left(\mathrm{kg} \cdot \mathrm{cm}^{-2}\right)$ \\
\hline Control & $22.88 \pm 3.50 \mathrm{c}^{\mathrm{z}}$ & $13.56 \pm 3.21 \mathrm{~b}$ & $9.74 \pm 1.37 \mathrm{ab}$ & $1.13 \pm 0.29 \mathrm{~b}$ \\
$1 / 2 \mathrm{G}$ & $25.27 \pm 3.55 \mathrm{~b}$ & $14.04 \pm 2.90 \mathrm{~b}$ & $10.07 \pm 1.67 \mathrm{ab}$ & $1.22 \pm 0.36 \mathrm{ab}$ \\
$1 / 2 \mathrm{G}+\mathrm{M} 9$ & $24.12 \pm 3.06 \mathrm{bc}$ & $13.93 \pm 2.50 \mathrm{~b}$ & $10.53 \pm 1.29 \mathrm{ab}$ & $1.37 \pm 0.39 \mathrm{a}$ \\
$\mathrm{G}$ & $29.33 \pm 4.55 \mathrm{a}$ & $18.01 \pm 5.75 \mathrm{a}$ & $10.71 \pm 2.66 \mathrm{a}$ & $1.14 \pm 0.28 \mathrm{~b}$ \\
$\mathrm{G}+\mathrm{M} 9$ & $29.42 \pm 2.17 \mathrm{a}$ & $16.34 \pm 2.18 \mathrm{a}$ & $9.58 \pm 1.40 \mathrm{~b}$ & $1.27 \pm 0.25 \mathrm{ab}$ \\
$P$ values & & & & \\
$\quad$ Girdling & $<\mathbf{0 . 0 0 1}$ & $<\mathbf{0 . 0 0 1}$ & 0.245 & 0.251 \\
$\quad$ Bridge grafting & 0.434 & 0.207 & 0.331 & $\mathbf{0 . 0 2 1}$ \\
Girdling $\times$ bridge grafting & 0.359 & 0.266 & $\mathbf{0 . 0 2 3}$ & 0.868 \\
\hline
\end{tabular}

${ }^{\mathrm{z}}$ Data within a row represent mean $\pm \mathrm{SE}, n=30$, different letters following the data are significantly different at $P<0.05$.

${ }^{\mathrm{y}}$ Effects of girdling and bridge grafting with $P<0.05$ are highlighted in bold.

$1 / 2 \mathrm{G}=$ semigirdling apple trees; $1 / 2 \mathrm{G}+\mathrm{M} 9$ = bridge-grafted $\mathrm{M}$ 9 on semigirdling apple trees; $\mathrm{G}=$ ring girdling apple trees; $\mathrm{G}+\mathrm{M} 9=$ bridge-grafted $\mathrm{M} 9$ on ring girdling apple trees. 
$(P<0.001)$. It was the lowest in $\mathrm{G}$ apple trees, highest in control apple trees, and intermediate in the other three treatments $(P<0.001$; Fig. 5A; Table 5). Similarly, the IAA concentration of the shoot terminals also gradually decreased in the five treatments of apple trees from June to Sept. $2016(P<0.001$; Fig. 5B). The control shoot tips showed the highest IAA concentrations. The removal of bark significantly affected the IAA content in the shoot terminals of apple trees $(P=0.001$; Table 5). The GA concentration in shoot terminals of $1 / 2 \mathrm{G}$ and $1 / 2 \mathrm{G}+\mathrm{M} 9$ increased from June to August $(P<0.001)$; however, in the latter case, it decreased from August to September similar to that in $\mathrm{G}+\mathrm{M} 9$ apple trees. GA decreased gradually in $\mathrm{G}$ apple trees. Furthermore, the GA content in $\mathrm{G}$ apple trees was higher than that in the other treatments from June to July, but decreased from July to September (Fig. 5C; Table 5). The ABA concentration of shoot terminals in the five treatments increased from June to August $(P<0.001)$; it was higher in $\mathrm{G}$ apple highest in G+M9 apple trees in September. By contrast, controls showed the lowest concentrations of ABA at all growth stages studied (Fig. 5D). Overall, debarking of the trunk $(P<0.001)$ and bridge grafting $(P=$ $0.048)$ significantly affected ABA concentration in apple tree shoots (Table 5).

Trunk wounding and bridge grafting significantly affected carbohydrates, starch, and soluble protein content $(P<0.05$, Table 5). The shoot tip carbohydrates in all apple trees decreased first and then increased (Fig. 6). The soluble sugar concentration was not significantly different from June to September. In July, the starch content in the shoot terminals in control and $1 / 2 \mathrm{G}$ apple trees was significantly lower than that in the other three treatments. The starch concentration in the control apple trees was the lowest, whereas it was intermediate in $1 / 2 \mathrm{G}$ and $\mathrm{G}$ apple trees in August. The starch content in $1 / 2 \mathrm{G}$ and $1 / 2 \mathrm{G}+\mathrm{M} 9$ apple trees was lower than that in trees than in the other treatments and was the

controls and $\mathrm{G}$ apple trees. Soluble sugar $(P=$ $0.023)$ and starch $(P<0.001)$ contents were significantly affected by the bridge-grafting treatment; however, the former was unaffected by the trunk-girdling treatment and the latter was increased by girdling $(P=0.006$; Table 2).

From June to September, soluble protein content in the shoot terminals of apple trees decreased gradually $(P<0.001)$. In June, the soluble protein content in $1 / 2 \mathrm{G}+\mathrm{M} 9$ and $\mathrm{G}+\mathrm{M} 9$ apple trees was higher than that in $1 / 2 \mathrm{G}$ and $\mathrm{G}$ apple trees $(P<0.001)$. In July, the soluble protein content in $\mathrm{G}+\mathrm{M} 9$ was higher than that in the other treatments. No significant difference was noted among the five treatments from August to September (Fig. 6C; Table 5).

\section{Discussion}

Bridge grafting of M9 restored partial tree vigor in trunk-wounded apple trees. Trunk wounding in fruit trees hinders the synthesis and transport of endogenous hormones; limits the growth of trees trunks, shoots, and roots; and restricts nutrient absorption (Choi et al., 2010). Overall, these changes lead to the loss of tree vigor (Greene and Lord, 1978; Hennerty and Forshey, 1971). Trunk girdling, a measure undertaken to counteract these adverse effects, which restricts the flow of carbohydrates down to the root, might have had varying effects on root development (Samad et al., 1999b). In the present study, girdling reduced the annual shoot length, plant height, and spring shoot number; however, bridge grafting of M9 did not have a significant effect (Figs. 2 and 3). This result suggested that the root status has a greater effect on vegetative growth than shoot status, likely via hormonal influences (Fig. 5).

In fruit trees, excessively low IAA content inhibits lateral branch formation and $\mathrm{ABA}$ accumulates in the axillary buds and shoot tips, thereby reducing lateral emergence

Table 4. Correlation coefficients among fruit characteristics, fruit size, and yield.

\begin{tabular}{lccccc}
\hline Correlation coefficients & Fruit wt & Soluble solids & Fruit diam & Fruit length & Yield \\
\hline Flesh firmness & -0.200 & 0.011 & -0.211 & $-0.255^{*}$ & $-0.611^{*}$ \\
Fruit weight & & -0.288 & $0.921^{* *}$ & $0.879^{* *}$ & 0.072 \\
Soluble solids & & & $-0.397^{*}$ & -0.241 & -0.123 \\
Fruit diameter & & & & $0.760^{* *}$ & -0.123 \\
Fruit length & & & & 0.229 \\
\hline
\end{tabular}

$* P<0.05 ; * * P<0.01$.
(Kim et al., 1984; Robinson, 2003). In the present study, from June to September in 2016, girdling decreased the IAA content and increased the ABA content in apple trees shoots, thereby reducing the shoot growth of $\mathrm{G}$ and $\mathrm{G}+\mathrm{M} 9$ apple trees and hindering shoot emergence (Figs. 2D, 3A, 5B and D; Bangerth, 1989; Brewer et al., 2009; Wang et al., 1994; Zhang et al., 2015). In addition, during rapid shoot growth, the starch and soluble protein contents in semigirdling and ring girdling apple trees were lower than those of the control providing insufficient energy for shoot development (Goren et al., 2004; Thorpe and Murashige, 1968). Previous studies showed that $\mathrm{GA}_{1}, \mathrm{GA}_{3}$, and $\mathrm{GA}_{4}$ can decrease the proportion of spurs and increase shoot length in fruit trees (Little and Macdonald, 2003). From May to July in 2016, during the shoot bud formation in apple trees, high concentration of GA in the G apple trees caused by girdling for wound healing increased the medium-long shoots (Zhang et al., 2015). However, bridge grafting of M9 increased the CTK content and decreased the GA content to promote more spurs. Furthermore, IAA promoted the growth and development of trees shoots, whereas ABA played an opposite role (Tworkoski and Fazio, 2016). In the present study, from June to September, trunk wounding decreased the IAA content owing to the reduction of vegetative growth and increased the ABA content, leading to the inhibition of tree growth and shoot formation in $1 / 2 \mathrm{G}, \mathrm{G}$, and G+M9 apple trees (Bangerth, 1989; Brewer et al., 2009; Wang et al., 1994). Because the girdling area of the trunk in $1 / 2 \mathrm{G}$ apple trees was smaller than that in $\mathrm{G}$ apple trees, the effect of bridge grafting M9 on shoot growth and branching ability was more prominent in the former.

Trunk wounding affects the assimilation function and development of trees leaves, including photosynthesis and leaf area (Tang et al., 2015). Girdling decreases leaf $g_{\mathrm{s}}, P \mathrm{n}$, and $\mathrm{Tr}$ in most species (Schechter and Proctor, 1994). A decrease in leaf $P \mathrm{n}$ of apple trees under wound stress is mainly caused by closing of the stomatal aperture, decline of RuBPcase activity, and accumulation of soluble sugar because of sink feedback inhibition of photosynthesis (Cheng et al., 2008; Quentin et al., 2013). In the present study, the leaf $P \mathrm{n}, \mathrm{Tr}, g_{\mathrm{s}}$, and SPAD were the lowest in $\mathrm{G}$ apple trees, after bridge-grafted M9 rootstock, which was transferred assimilates from

Table 5. $P$ values of the contents of endogenous hormones, carbohydrates, and soluble protein (2016) of shoot terminals in apple trees among girdling treatments, bridge grafting, and growth time produced using a three-way factorial analysis of variance.

\begin{tabular}{lcccrrrr}
\hline & $\begin{array}{c}\text { Zeatin riboside } \\
\text { content }\end{array}$ & $\begin{array}{c}\text { Indole acetic } \\
\text { acid content }\end{array}$ & $\begin{array}{c}\text { Gibberellic } \\
\text { acid content }\end{array}$ & $\begin{array}{c}\text { Abscisic acid } \\
\text { content }\end{array}$ & $\begin{array}{c}\text { Soluble sugar } \\
\text { content }\end{array}$ & Starch content & $\begin{array}{c}\text { Soluble protein } \\
\text { content }\end{array}$ \\
\hline values & $<\mathbf{0 . 0 0 1}$ & $\mathbf{0 . 0 0 1}$ & $<\mathbf{0 . 0 0 1}$ & $<\mathbf{0 . 0 0 1}$ & 0.573 & 0.076 & $\mathbf{0 . 0 1 2}$ \\
Girdling & $<\mathbf{0 . 0 0 1}$ & 0.627 & $<\mathbf{0 . 0 0 1}$ & $\mathbf{0 . 0 4 8}$ & $\mathbf{0 . 0 2 3}$ & $\mathbf{0 . 0 0 6}$ & $<\mathbf{0 . 0 0 1}$ \\
Bridge grafting & $\mathbf{0 . 0 2 2}$ & 0.894 & $\mathbf{0 . 0 1 1}$ & 0.312 & 0.366 & 0.925 & $\mathbf{0 . 0 4 7}$ \\
Girdling $\times$ bridge grafting & $<\mathbf{0 . 0 0 1}$ & $<\mathbf{0 . 0 0 1}$ & $<\mathbf{0 . 0 0 1}$ & $<\mathbf{0 . 0 0 1}$ & $<\mathbf{0 . 0 0 1}$ & $<\mathbf{0 . 0 0 1}$ & $<\mathbf{0 . 0 0 1}$ \\
Time & $\mathbf{0 . 0 0 4}$ & 0.369 & $<\mathbf{0 . 0 0 1}$ & $<\mathbf{0 . 0 0 1}$ & 0.907 & $<\mathbf{0 . 0 0 1}$ & $\mathbf{0 . 0 2 3}$ \\
Girdling $\times$ time & $\mathbf{0 . 0 1 4}$ & 0.718 & $<\mathbf{0 . 0 0 1}$ & $<\mathbf{0 . 0 0 1}$ & 0.117 & $<\mathbf{0 . 0 0 1}$ \\
Bridge grafting $\times$ time & 0.586 & 0.777 & $<\mathbf{0 . 0 0 1}$ & $<\mathbf{0 . 0 0 1}$ & 0.282 & 0.053 \\
Girdling $\times$ bridge grafting $\times$ time & $\mathbf{0 . 0 2 3}$ & 0.279 \\
\hline
\end{tabular}

${ }^{\mathrm{z}}$ Effects of girdling and bridge grafting with $P<0.05$ are highlighted in bold. 


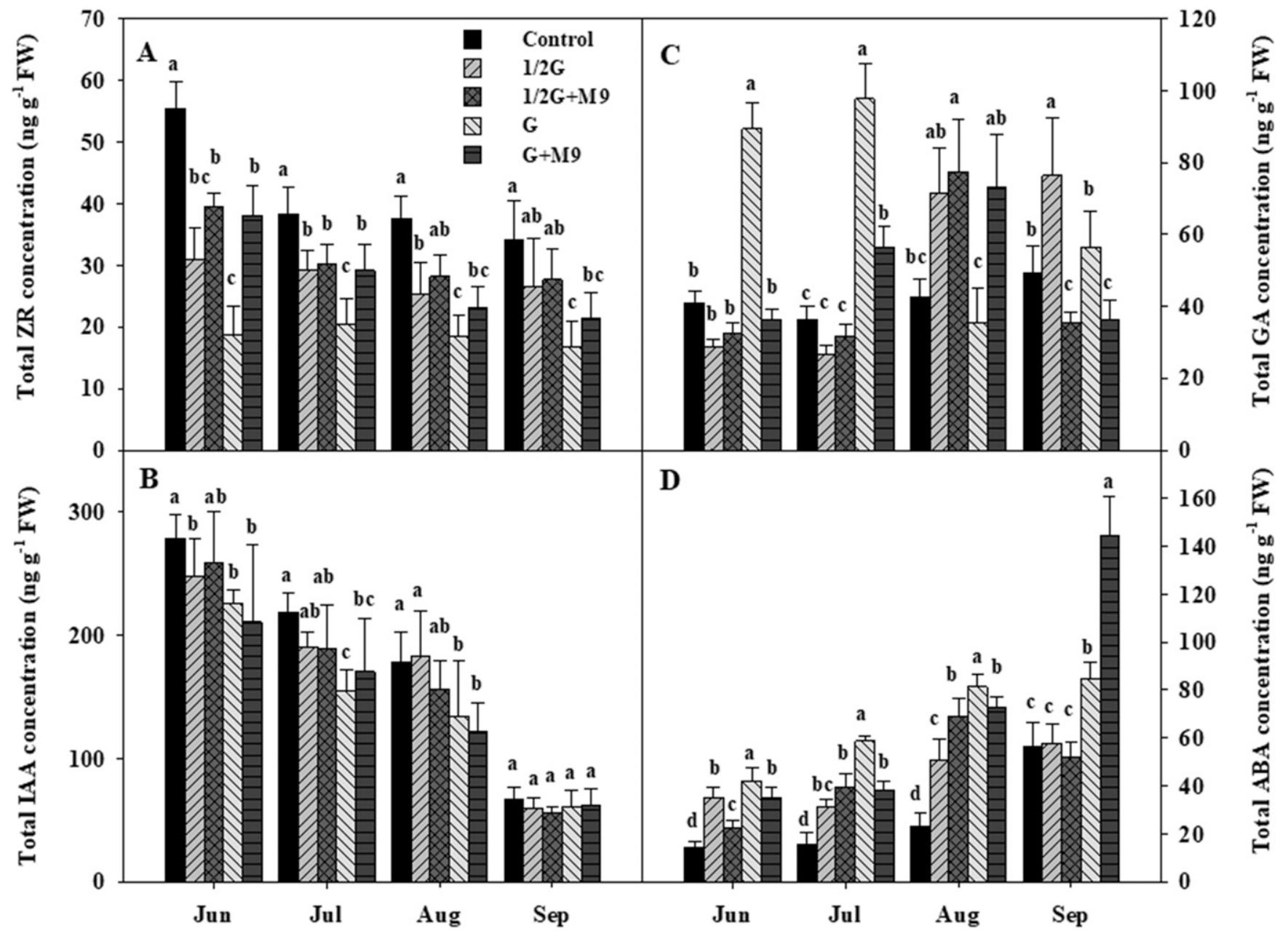

Fig. 5. Effects of semigirdling, ring girdling, and bridge grafting of M9 on dynamic changes in endogenous hormone contents of shoot terminals in 'Nagafu 2 ' trees from June to September in 2016. Control = no girdling or no bridge grafting apple trees; $1 / 2 \mathrm{G}=$ semigirdling apple trees; $1 / 2 \mathrm{G}+\mathrm{M} 9=$ bridge-grafted $\mathrm{M} 9$ on semigirdling apple trees; $\mathrm{G}=$ ring girdling apple trees; $\mathrm{G}+\mathrm{M} 9=$ bridge-grafted $\mathrm{M} 9$ on ring girdling apple trees. Dots represent mean $\pm \mathrm{SE}, n=9$. Different letters above the bars indicate a significant difference at $P<0.05$ at different times. $\mathrm{ABA}=$ abscisic acid; $\mathrm{GA}=$ gibberellin acid; $\mathrm{IAA}=\mathrm{indole}$ acetic acid, $\mathrm{ZR}=$ zeatin riboside.

Table 6. Apple fruit characteristic and production at different treatments and $P$ values of main effects between girdling and bridge grafting produced using a twoway factorial analysis of variance.

\begin{tabular}{|c|c|c|c|c|c|c|c|c|}
\hline Treatments & Yield $(\mathrm{kg} /$ tree $)$ & Fruit wt $(\mathrm{g})$ & $\begin{array}{c}\text { Fruit } \\
\text { diam }(\mathrm{mm})\end{array}$ & $\begin{array}{c}\text { Fruit } \\
\text { length }(\mathrm{mm})\end{array}$ & $\begin{array}{c}\text { Fruit shape } \\
\text { index }\end{array}$ & Peel redness $\left(\triangle \mathrm{a}^{+}\right)^{\mathrm{z}}$ & $\begin{array}{l}\text { Soluble-solid } \\
\text { content }(\%)\end{array}$ & $\begin{array}{c}\text { Maturity } \\
\text { index }\end{array}$ \\
\hline $1 / 2 \mathrm{G}$ & $8.69 \pm 0.74 \mathrm{c}$ & $210.18 \pm 46.92 b$ & $79.10 \pm 5.13 b$ & $64.88 \pm 6.96 \mathrm{~b}$ & $0.82 \pm 0.05 \mathrm{a}$ & $20.68 \pm 3.49 a$ & $14.80 \pm 1.04 \mathrm{~b}$ & $6.67 \pm 1.03 \mathrm{a}$ \\
\hline $1 / 2 \mathrm{G}+\mathrm{M} 9$ & $19.21 \pm 3.14 \mathrm{ab}$ & $268.04 \pm 41.77 \mathrm{a}$ & $86.13 \pm 5.48 \mathrm{a}$ & $72.11 \pm 5.73 \mathrm{a}$ & $0.84 \pm 0.07 \mathrm{a}$ & $18.67 \pm 3.22 \mathrm{a}$ & $15.50 \pm 1.33 \mathrm{~b}$ & $6.67 \pm 0.52 \mathrm{a}$ \\
\hline $\mathrm{G}+\mathrm{M} 9$ & $18.00 \pm 3.71 b$ & $254.75 \pm 42.95 \mathrm{a}$ & $83.47 \pm 5.27 \mathrm{a}$ & $71.49 \pm 3.93 \mathrm{a}$ & $0.86 \pm 0.04 \mathrm{a}$ & $20.25 \pm 4.27 \mathrm{a}$ & $14.07 \pm 1.24 \mathrm{~b}$ & $7.00 \pm 0.63 \mathrm{a}$ \\
\hline \multicolumn{9}{|l|}{$P$ values } \\
\hline Girdling & $<0.001^{x}$ & $<0.001$ & $<0.001$ & $<0.001$ & 0.428 & $<0.001$ & 0.064 & 0.34 \\
\hline
\end{tabular}

${ }^{\mathrm{z}}$ The larger the value represents, the deeper the red color of the apple peel.

${ }^{\mathrm{y}}$ Data within a row represent mean $\pm \mathrm{sE}, n=30$, different letters following the data are significantly different at $P<0.05$.

${ }^{\mathrm{x}}$ Effects of girdling and bridge grafting with $P<0.05$ are highlighted in bold.

$1 / 2 \mathrm{G}=$ semigirdling apple trees; $1 / 2 \mathrm{G}+\mathrm{M} 9=$ bridge-grafted $\mathrm{M} 9$ on semigirdling apple trees; $\mathrm{G}=$ ring girdling apple trees; $\mathrm{G}+\mathrm{M} 9=$ bridge-grafted $\mathrm{M} 9$ on ring girdling apple trees.

upon girdling to M9 rootstock to reduce the inhibition of sink feedback (Neales and Incoll, 1968). Second, in $1 / 2 \mathrm{G}$ apple trees, although they were recovered by bridge grafting of M9, the $\operatorname{Tr}$ increased after $g_{\mathrm{s}}$ increased in apple trees (Williams et al., 2000). In addition, bridge-grafted M9 increased the leaf area and SPAD values, followed by an increase in Pn (Peng and Rabe, 1996).

Bridge grafting of M9 increased flowering and fruiting in trunk-wounded apple trees. The aforementioned results indicated that bridge grafting of M9 supplemented certain nutritional factors or hormones for leaf growth, facilitated the partial recovery of the lost vigor, and maintained the reduction of vegetative growth. M9 rootstocks absorbed the deposited carbohydrates in the overground part to accelerate the leaf photosynthesis rate in trunk-wounded apple trees (Table 2) (Goren and Monselise, 1971; Noel, 1970). 


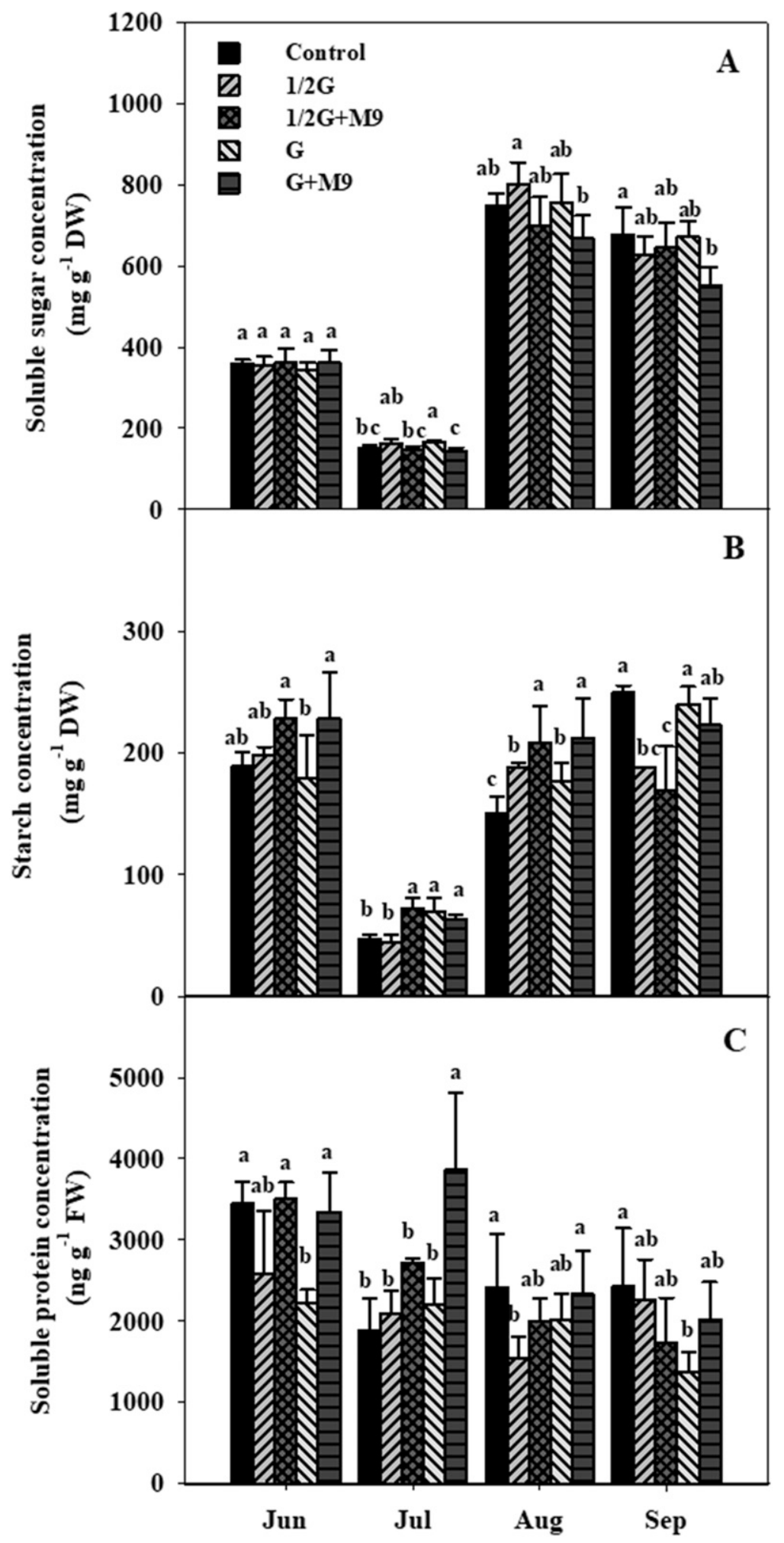

Fig. 6. Effects of semigirdling, ring girdling, and bridge grafting of M9 on dynamic changes in soluble sugars (A), starch (B), and soluble protein $(\mathbf{C})$ contents in shoot terminals of 'Nagafu 2' trees from June to September in 2016. Control $=$ no girdling or no bridge grafting apple trees; $1 / 2 \mathrm{G}=$ semigirdling apple trees; $1 / 2 \mathrm{G}+\mathrm{M} 9$ = bridge-grafted $\mathrm{M} 9$ on semigirdling apple trees; $\mathrm{G}=$ ring girdling apple trees; $\mathrm{G}+\mathrm{M} 9=$ bridge-grafted M9 on ring girdling apple trees. Dots represent mean $\pm \mathrm{SE}, n=9$. Different letters above the bars indicate a significant difference at $P<0.05$ at different times.

Trunk wounding was found to weaken tree vigor, lead to poor and stunted floral buds, and affect flowering and fruit-set in 2017 (Hartmann and Kester, 1975; Jędrzejuk et al., 2016; Li et al., 2012, 2017; Sun et al.,
2004). The results of correlation coefficient analysis between flowering and proportion of spurs and branching ability confirmed that they have a significantly positive correlation (Table 2). Hence, trunk girdling led to the reduction of flowering and fruit-set in $1 / 2 \mathrm{G}$ and $G$ 'Nagafu 2' trees and both were increased by bridge grafting M9 to renew partial tree vigor (Table 1; Supplemental Fig. 2).

Furthermore, high CTK content and low GA content were found to be beneficial for flower bud formation (Sanyal and Bangerth, 1998; Zhang et al., 2015). McLaughlin and Greene (1991) indicated that spraying exogenous CTK facilitates the formation of flower bud in apple trees. In general, CTK is synthesized by plant roots; girdling inhibits the growth of fruit tree roots and, hence, decreases the synthesis of CTK (Cutting and Lyne, 1993; Dann et al., 1984). The period from May to September is the peak growth period of apple trees, whereas girdling hinders the downward transport of photosynthates, thereby limiting root growth and CTK synthesis (An et al., 2017; Havelange et al., 2000). In the present study, the $Z R$ content in the $\mathrm{G}+\mathrm{M} 9$ treatment was higher than that in the $G$ treatment (Fig. 5A). During flower bud formation, bridge grafting of M9 has been found to promote tree body ZR content and nutrients to stimulate flower bud differentiation. However, high levels of $\mathrm{GA}_{1}, \mathrm{GA}_{3}$, $\mathrm{GA}_{4}$, and iso-GA $\mathrm{G}_{7}$ inhibit flower bud formation, although they play an important role in the physiological differentiation of flower buds (Ramírez et al., 2004). In addition, high GA content in $\mathrm{G}$ treatment inhibited flower bud formation from June to July (Figs. 2A and 5C; Supplemental Fig. 2).

The content of metabolic substrates (such as soluble proteins, amino acids, and carbohydrates) showed a close relationship with floral formation in the tree body (Sun et al., 2004). In the present study, soluble protein content $(P=0.012$, Table 5), but not carbohydrate content, was the most important metabolite to affect flower differentiation $(P>$ 0.05 ) in trunk-wounded apple tree body. Thus, bridge grafting of M9 recovered the vitality of the tree body to increase the accumulation of soluble protein in the shoot of trunk-wounded apple trees for aiding floral induction (Tables 1 and 5; Fig. 6C; Liu et al., 2011).

Bridge grafting of $M 9$ restored yield and fruit quality in trunk-wounded apple trees. Girdling has been widely confirmed to affect fruit characteristics and yield, but different results have been obtained in various fruit trees. For example, Peng and Rabe (1996) showed that girdling on Citrus unshiu Marc significantly decreased yield and tree vigor tended to produce smaller fruit, but Rivas et al. (2006) suggested that girdling could improve fruit-set. Some researchers believed that ring girdling at an appropriate time and such methods could enhance fruit size and color, but they obtained the opposite consequence with excessive and early girdling (Agusti et al., 1998; Morandi et al., 2011). However, little is known about the effect of bridge grafting on fruit quality in trunkwounded 'Red Fuji' trees. Our study indicated that the wider the girdling trunk bark area, the lower the yield. This attributed to not only lower flowering and fruit-setting but also high fruit dropping before fruit 
maturation (Fig. 2A and B; Table 6) because weakened tree vigor in girdled apple tree reduced the leaf photosynthesis and leaf area, leading to the decline of the capacity of fruit load and growth (Wargo et al., 2004). However, bridge-grafted M9 on trunk-wounded apple trees promoted nutrient absorption and increased vigor and viability, as well as increased of the leaf photosynthesis rate and leaf area (Figs. 3B and 4), to enhance fruit load and size (Vaio et al., 2009; Wilton, 2000). Large apple fruits are softer than small (Blanpied et al., 1978; Samad et al., 1999a). Flesh firmness had a negative correlation with yield and fruit length (Table 4), which indicates that not only fruit size but also fruit load affects flesh firmness (Stopar et al., 2002). However, fruit firmness in $1 / 2 \mathrm{G}+\mathrm{M} 9$ and $\mathrm{G}+\mathrm{M} 9$ apple trees was higher than in control in similar fruit size and load, which displayed that bridge grafting of M9 affects the fruit firmness, but the basic regulatory mechanism is still unknown. Moreover, in the present study, assimilates accumulated on ring girdling that increased fruit soluble-solid content, which corresponded with the finding of Arakawa et al. (1997, 1998). The declined fruit-setting in $\mathrm{G}$ apple trees may lead to the increasing of fruit soluble-solid content, compared with $\mathrm{G}+\mathrm{M} 9$ apple trees (Fig. 2B; Table 4). Bridge grafting of M9 on trunkwounded apple trees led to partial recovery of remarkably decreased fruit color to control levels (Table 6). Meanwhile, the fruit maturity index in the five treatments had no significant difference (Table 6). We speculated that fruit color might be related to certain nutrients and substances from the roots (DeEll et al., 2001; Ji et al., 2015; Liu et al., 2017).

\section{Conclusion}

Bridge grafting of M9-T337 self-rooted rootstock on trunk-wounded apple trees effectively recovered partial tree vigor and, importantly, restored yield and fruit characteristics to control levels. The vegetative growth under bridge-grafted M9 treatment was not significantly different from that after ring girdling of 'Nagafu 2' trees; this could be attributed to the extraordinary function of M9 dwarfing rootstock. The bridge grafting of M9 treatments was successful in maintaining the reduction of vegetative growth but increased reproductive growth in the trunkwounded 'Nagafu 2' trees and could thus represent an effective strategy to combat $V a l s a$-induced trunk wounding in apple trees.

\section{Literature Cited}

Abe, K., N. Kotoda, H. Kato, and J. Soejima. 2007. Resistance sources to Valsa canker (Valsa ceratosperma) in a germplasm collection of diverse Malus species. Plant Breeding 126:449453.

Agusti, M., I. Andreu, M. Juan, V. Almela, and L. Zacarias. 1998. Effects of ringing branches on fruit size and maturity of peach and nectarine cultivars. J. Hort. Sci. Biotechnol. 73(4):537540.
An, H., F. Luo, T. Wu, Y. Wang, X. Xu, X. Zhang, and Z. Han. 2017. Dwarfing effect of apple rootstocks is intimately associated with low number of fine roots. HortScience 52:503-512.

Arakawa, O., K. Kanno, A. Kanetsuka, and Y. Shiozaki. 1997. Effect of girdling and bark inversion on tree growth and fruit quality of apple. Acta Hort. 451:579-586.

Arakawa, O., K. Kanno, A. Kanetsuka, and Y. Shiozaki. 1998. Effects of five methods of bark inversion and girdling on the tree growth and fruit quality of 'Megumi' apple. J. Jpn. Soc. Hort. Sci. 67(5):721-727.

Bangerth, F. 1989. Dominance among fruit/sinks and the search for acorrelative signal. Physiol. Plant. 76:608-614.

Beruter, J., M. Feusi, and E. Studer. 1997. The effect of girdling on carbohydrate partitioningin the growing apple fruit. J. Plant Physiol. 151:277-285.

Blanpied, G.D., W.J. Bramlage, D.H. Dewey, R.L. Lalelle, L.M. Massey, Jr., G.E. Mattus, W.C. Stiles, and A.E. Watalla. 1978. A standardized method for collecting apple pressure test data. Cornell Expt. Sta. Bul. 74.

Blanpied, G.D. and K.J. Silsby. 2010. Generic starch iodine index chart for apples. Predicting harvest date windows for apples. A Cornell Coop. Ext. Publ., Info. Bul. 221.

Brewer, P.B., E.A. Dun, B.J. Ferguson, C. Rameau, and C.A. Beveridge. 2009. Strigolactone acts downstream of auxin to regulate bud outgrowth in pea and Arabidopsis. Plant Physiol. 150(1):482-493.

Cao, K., L. Guo, B. Li, G. Sun, and H. Chen. 2009. Investigations on the occurrence and control of apple canker in China. Plant Protection 35(2):114-117.

Cheng, Y., O. Arakawa, M. Kadai, and S. Sawada. 2008. Analysis of reduced photosynthesis in the apple leaf under sink-limited conditions due to girdling. J. Jpn. Soc. Hort. Sci. 77(2):115-121.

Choi, S.T., W.D. Song, D.S. Park, and S.M. Kang. 2010. Effect of different girdling dates on tree growth, fruit characteristics and reserve accumulation in a late-maturing persimmon. Scientia Hort. 126(2):152-155.

Cutting, J.G.M. and M.C. Lyne. 1993. Girdling and the reduction in shoot xylem sap concentrations of cytokinins and gibberellins in peach. J. Hort. Sci. 68(4):619-626.

Dann, I.R., P.H. Jerie, and D.J. Chalmers. 1985 Short-term changes in cambial growthand endogenous IAA concentrations in relation to phloem girdling of peach, Prunus persica (L.) Batch. Austral. J. Plant Physiol. 12:392-402.

Dann, I.R., R.A. Wilders, and D.J. Chalmes. 1984 Effects of limb girdling on growth and development of competing fruit and vegetative tissues of peach trees. Austral. J. Plant Physiol. 11:49-58.

DeEll, J.R., S. Khanizadeh, F. Saad, and D.C. Ferree. 2001. Factors affecting apple fruit firmness- A review. J. Amer. Pomol. Soc. 55(1):8-27.

Fanwoua, J., E. Bairam, M. Delaire, and G. BuckSorlin. 2014. The role of branch architecture in assimilate production and partitioning: The example of apple (Malus domestica). Front. Plant Sci. 5:338.

Goren, R., M. Huberman, and E.E. Goldschmidt. 2004. Girdling: Physiological and horticultural aspects. Vol. 30, p. 1-36. In: J. Janick (ed.). Horticultural reviews. Wiley Press, John Wiley Sons, Inc., Oxford, UK.

Goren, R. and S.P. Monselise. 1971. Effects of ringing on yields of low-bearing orange trees (Citrus sinensis [L.] Osbeck). J. Hort. Sci. 46:435-441.
Greene, D.W. and W.J. Lord. 1978. Evaluation of scoring, limb spreading and growth regulators for increasing flower bud initiation and fruit set on young Delicious apple trees. J. Amer. Soc. Hort. Sci. 103:208-210.

Hartmann, H.T. and D.E. Kester. 1975. Plant propagation: Principles and practices. 3rd ed. Prentice-Hall, Englewood Cliffs, NJ.

Havelange, A., P. Lejeune, and G. Bernier. 2000. Sucrose/cytokinin interaction in Sinapis alba at floral induction: A shoot-to-root-to-shoot physiological loop. Physiol. Plant. 109:343-350.

Hennerty, M.J. and G.G. Forshey. 1971. Effects of defruiting, scoring, defoliation and shading on the carbohydrate content of Golden Delicious apple trees. J. Hort. Sci. 46:153-161.

Hu, Y., Q. Dai, Y. Liu, Z. Yang, N. Song, X. Gao, R.T. Voegele, Z. Kang, and L. Huang. 2014. Agrobacterium tumefaciens-mediated transformation of the causative agent of Valsa canker of apple tree Valsa mali var. mali. Curr. Microbiol. 68(6):769-776.

Jędrzejuk, A., J. Rabiza-Świder, E. Skutnik, and M. Serek. 2016. Flowering conditions affect flower longevity in Syringa vulgaris and cause changes in protein content, protease activity and expression of a KDEL-CysEP gene. Acta Physiol. Plant. 38:45.

Ji, X.H., Y.T. Wang, R. Zhang, S.J. Wu, M.M. An, M. Li, Y.M. Zhang, and X.S. Chen. 2015. Effect of auxin, cytokinin and nitrogen on anthocyanin biosynthesis in callus cultures of red-fleshed apple (Malus sieversii f. niedzwtzkyana). Plant Cell Tissue Organ Cult. 120(1):325-337.

Jordan, M.O. and R. Habib. 1996. Mobilizable carbon reserves in young peach trees asevidenced by trunk girdling experiments. J. Expt. Bot. 47:79-87.

Kim, Y.K., B.H. Howard, and J.D. Quinlan. 1984. Apparent ABA-induced inhibition of the lower laterals of one-year-old cherry trees. J. Hort. Sci. 59(1):35-44.

Lee, D.H., S.W. Lee, K.H. Chi, D.K. Kim, and J.Y. Uhm. 2006. Survey on the occurrence of apple disease in Korea from 1992 to 2000. Plant Pathol. J. 22:375-380.

Li, H.L., H. Zhang, C. Yu, L. Ma, Y. Wang, X.Z. Zhang, and Z.H. Han. 2012. Possible roles of auxin and zeatin for initiating the dwarfing effect of M9 used as apple rootstock or interstock. Acta Physiol. Plant. 34(1):235-244.

Li, Y., D. Zhang, L. Zhang, X. Zuo, S. Fan, X. Zhang, A. Shalmani, and M. Han. 2017. Identification and expression analysis of cytokinin response-regulator genes during floral induction in apple (Malus domestica Borkh). Plant Growth Regulat. 83(3):455-464.

Little, C.H. and J.E. Macdonald. 2003. Effects of exogenous gibberellin and auxin on shoot elongation and vegetative bud development in seedlings of Pinus sylvestris and Picea glauca. Tree Physiol. 23(2):73.

Liu, X.J., X.H. An, X. Liu, X.F. Wang, C.X. You, and Y.J. Hao. 2017. MdSnRK1.1 interacts with MdJAZ18 to regulate sucrose-induced anthocyanin and proanthocyanidin accumulation in apple. J. Expt. Bot. 68(11):2977-2990.

Liu, Z.L., S.Q. Lin, and H.B. Chen. 2011. Relationships between nucleic acids, proteins and flower bud formation in Loquat. Acta Hort. 887:197-202.

Ma, Z., R. Wang, W. Liu, K. Kang, and P. Gao. 2007. Study on apple-tree canker on the peak fruit period in weibei area of Shaanxi. North. Hort. 10:210-212.

McLaughlin, J.M. and D.W. Greene. 1991. Fruit and hormones influence flowering of apple. II. 
Effects of hormones. J. Amer. Soc. Hort. Sci. 116:450-453.

Morandi, B., M. Zibordi, P. Losciale, L. Manfrni, E. Pierpaoli, and L.C. Grappadelli. 2011. Shading decreases the growth rate of young apple fruit by reducing their phloem import. Scientia Hort. 127(3):347-352.

Neales, T.F. and I.D. Incoll. 1968. The control of leaf photosynthesis rate by the level of assimilates concentration in the leaf: A review of the hypothesis. Bot. Rev. 34:107-125.

Noel, A.R.A. 1970. The girdled tree. Bot. Rev. 36:162-193.

Peng, Y.H. and E. Rabe. 1996. Effect of summer trunk girdling on fruit quality, maturation, yield, fruit size and tree performance in 'Mihowase' satsumas. J. Hort. Sci. 71(4):581-589.

Poirier-Pocovi, M. and G. Buck-Sorlin. 2016. Modelling temporal variation of parameters used in two photosynthesis models: Influence of fruit load and girdling in fruit bearing branches of apple trees. Functional-Structural Plant Growth Modeling, Simulation, Visualization and Applications (FSPMA), Intl. Conf. IEEE 167-174.

Quentin, A.G., D.C. Close, L.M.H.P. Hennen, and E.A. Pinkard. 2013. Down-regulation of photosynthesis following girdling, but contrasting effects on fruit set and retention, in two sweet cherry cultivars. Plant Physiol. Biochem. 73:359-367.

Ramírez, H., J. Torres, A. Benavides, J. Hernández, and V. Robledo. 2004. Fruit bud initiation in apple cv Red Delicious linked to gibberellins and cytokinins. J. Mex. Chem. Soc. 48:7-10.

Rivas, F., Y. Erner, E. Alós, M. Juan, V. Almela, and M. Agustí. 2006. Girdling increases carbohydrate availability and fruit-set in citrus cultivars irrespective of parthenocarpic ability. J. Hort. Sci. Biotechnol. 81:289-295.

Robinson, T.L. 2003. Apples: Botany, production and uses, p. 345-408. In: D.C. Ferree and I.J. Warrington (eds.) Apple- orchard planting systems. CABI Publ., Wallingford, UK.

Rose, R., C.L. Rose, S.K. Omi, K.R. Forry, D.M. Durall, and W.L. Bigg. 1991. Starch determination by perchloric acid vs enzymes evaluating the accuracy and precision of six colormetric methods. J. Agr. Food Chem. 39:2-11.

Samad, A., D.L. McNeil, M.M. Bunker, and Z.U. Khan. 1999a. Effect of interstock bridge grafting on fruit quality at harvest and during storage of four apple cultivars. Pak. J. Biol. Sci. 2(3):969-973.

Samad, A., D.L. McNeil, and Z.U. Khan. 1999b. Effect of interstock bridge grafting (M9 dwarfing rootstock and same cultivar cutting) on vegetative growth, reproductive growth and carbohydrate composition of mature apple trees. Scientia Hort. 79:23-28.

Sanyal, D. and F. Bangerth. 1998. Stress induced ethylene evolution and its possible relationship to auxin-transport, cytokinin levels, and flower bud induction in shoots of apple seedlings and bearing apple trees. Plant Growth Regulat. 24:127-134.

Schechter, I. and J.T.A. Proctor. 1994. Apple fruit removal and limb girdling affect fruit and leaf characteristics. J. Amer. Soc. Hort. Sci. 119:157-162.

Singh, D., W. Dhillon, N. Singh, and G. Pps. 2015. Effect of girdling on leaf nutrient levels in pear cultivars Patharnakh and Punjab Beauty. Indian J. Hort. 72(3):319.

Skogerbo, G. 1992. Effect of root pruning and trunk girdling on xylem cytokinin content of apple (Malus $\times$ domestica Borkh.). Nor. J. Agr. Sci. 6:499-507.

Stopar, M., U. Bolcina, A. Vanzo, and U. Vrhovsek. 2002. Lower crop load for cv. Jonagold apples (Malus $\times$ domestica Borkh.) increases polyphenol content and fruit quality. J. Agr. Food Chem. 50(6):1643-1646.

Sun, X., W. Li, L. Wang, G. Zhu, and W. Fang. 2004. Changes of protein, amino acid and carbohydrate during flower bud differentiation of peach. J. Gansu Agr. Univ. 39(3):295-299.

Tan, Y., S. Lv, X. Liu, T. Gao, T. Li, Y. Wang, T. $\mathrm{Wu}, \mathrm{X}$. Zhang, Y. Han, S.S. Korban, and Z. Han. 2017. Development of high-density interspecific genetic maps for the identification of QTLs conferring resistance to Valsa ceratosperma in apple. Euphytica 213:10.

Tang, G., X. Li, L. Lin, Z. Guo, C. Li, H. Guo, and F. Zeng. 2015. Impact of phloem girdling on water status in desert plants Alhagi sparsifolia Shap. (Fabaceae) and Karelinia caspica (Pall.) Less.(Asteraceae). Braz. J. Bot. 38(4):717728.

Thorpe, T. and T. Murashige. 1968. Starch accumulation in shoot-forming tobacco callus cultures. Science 160(3826):421-422.
Tworkoski, T. and G. Fazio. 2016. Hormone and growth interactions of scions and sizecontrolling rootstocks of young apple trees. Plant Growth Regulat. 78(1):105-119.

Vaio, C.D., C. Cirillo, M. Buccheri, and F. Limongelli. 2009. Effect of interstock (M.9 and M. 27) on vegetative growth and yield of apple trees (cv “Annurca"). Scientia Hort. 119:270274.

Wang, C., X. Dong, Z. Zhang, G. Li, and B. Li. 2014. Outbreak and the reasons of apple Valsa canker in Yantai apple producing area in 2011. Agr. Sci. Technol. 15(1):83-86.

Wang, L., R. Zang, L.L. Huang, F.Q. Xie, and X.N Gao. 2005. The investigation of apple tree Valsa canker in Guanzhong region of Shaanxi province. J. Northwest Sci.-Tech. Univ. Agr. For. 33(Suppl):98-100.

Wang, S.Y., M. Faust, and M.J. Line. 1994. Apical dominance in apple (Malus domestica Borkh): The possible role of indole-3acetic acid (IAA). J. Amer. Soc. Hort. Sci. 119:1215-1221.

Wargo, J.M., I.A. Merwin, and C.B. Watkins. 2004. Nitrogen fertilization, midsummer trunk girdling, and AVG treatments affect maturity and quality of 'Jonagold' apples. HortScience 39:493-500.

Williams, L.E., W.A. Retzlaff, W. Yang, P.J. Biscay, and N. Ebisuda. 2000. Effect of girding on leaf gas exchange, water status, and nonstructural carbohydrates of field-grown Vitis vinifera L. (cv. Flame Seedless). Amer. J. Enol. Viticult. 51:49-54.

Wilton, J. 2000. Girdling studies. Orchardist 73(10): $14-17$.

Yemm, E.W. and A.J. Willis. 1954. The estimation of carbohydrates in plant extracts by anthrone. Biochem. J. 3:508-514

Zhang, M., M. Han, F. Ma, and H. Shu. 2015. Effect of bending on the dynamic changes of endogenous hormones in shoot terminals of 'Nagafu 2' and 'Gala' apple trees. Acta Physiol. Plant. 37:76.

Zhou, C.P., Y.P. Qi, L.T. Yang, P. Guo, X. Ye, X.X. Zhou, F.J. Ke, and L.S. Chen. 2013. Leaf cDNA-AFLP analysis of two citrus species differing in manganese tolerance in response to long-term manganese-toxicity. BMC Genomics 14:621. 


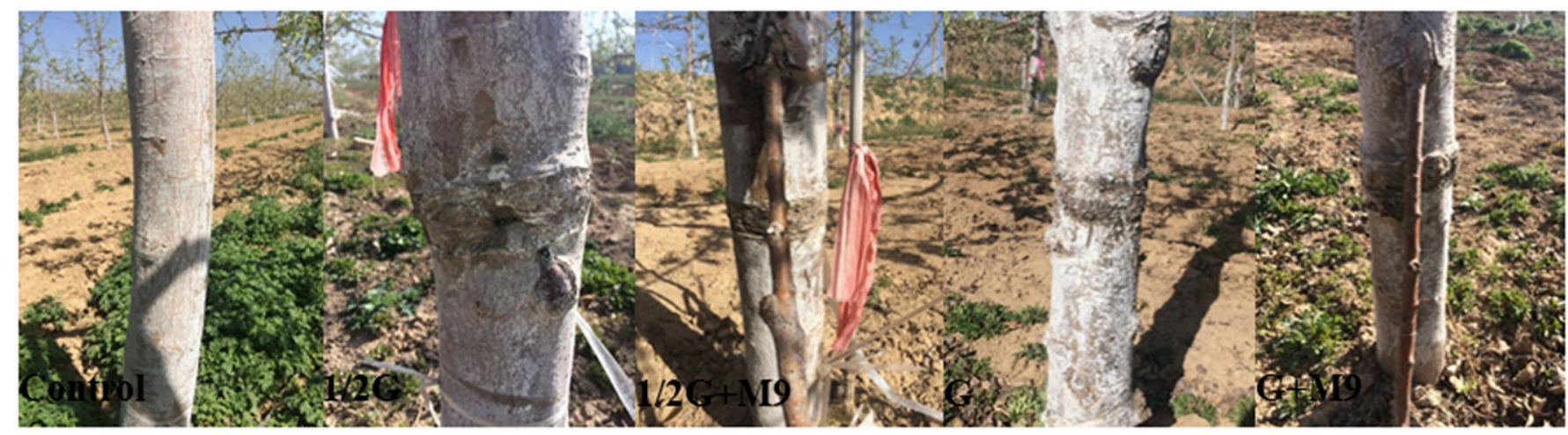

Supplemental Fig. 1. Photographs of different treatments in 'Nagafu 2' trees in 2017. Control $=$ no girdling or no bridge grafting apple trees; $1 / 2 \mathrm{G}=$ semigirdling apple trees; $1 / 2 \mathrm{G}+\mathrm{M} 9$ = bridge-grafted $\mathrm{M} 9$ on semigirdling apple trees; $\mathrm{G}=$ ring girdling apple trees; $\mathrm{G}+\mathrm{M} 9=$ bridge-grafted $\mathrm{M} 9$ on ring girdling apple trees.

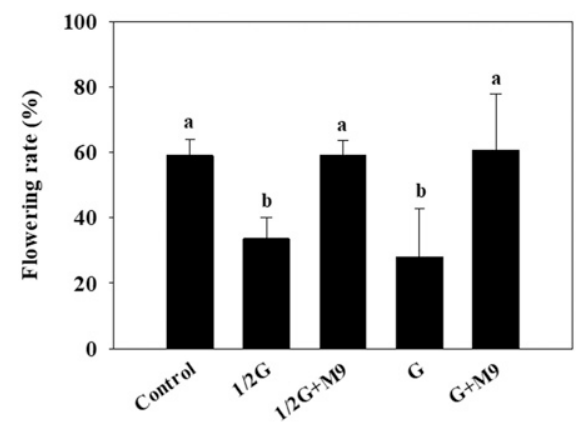

Supplemental Fig. 2. Effects of semigirdling, ring girdling, and bridge grafting of M9 on flowering rate in 'Nagafu 2 ' trees. Control = no girdling or no bridge grafting apple trees; $1 / 2 \mathrm{G}=$ semigirdling apple trees; $1 / 2 \mathrm{G}+\mathrm{M} 9=$ bridge-grafted $\mathrm{M} 9$ on semigirdling apple trees; $\mathrm{G}=$ ring girdling apple trees; $\mathrm{G}+\mathrm{M} 9$ = bridgegrafted M9 on ring girdling apple trees. Bars represent mean $\pm \mathrm{SE}, n=3$. Different letters above the bars indicate a significant difference at $P<0.05$. 